\title{
Influence of Outdoor Air Pollution on Cardiovascular Diseases in Madeira (Portugal)
}

\author{
Irene Camacho $\mathbb{D} \cdot$ Jaime Camacho • \\ Roberto Camacho • André Góis $(\mathbb{D} \cdot$ V Vítor Nóbrega (i)
}

Received: 20 August 2019/Accepted: 20 January 2020/Published online: 18 February 2020

(C) Springer Nature Switzerland AG 2020

\begin{abstract}
Previous studies suggest that human exposure to atmospheric pollution can trigger cardiovascular diseases (CVDs). This study aimed at assessing the influence of short-term exposure to atmospheric pollution in the occurrence of CVD and mortality in Madeira. A single-centre retrospective study was conducted during 2005-2011. Air pollutant data and meteorological parameters were
\end{abstract}

Irene Camacho, Jaime Camacho, Roberto Camacho, André Góis and Vítor Nóbrega contributed equally to this work.

I. Camacho $(\bowtie)$

Faculty of Life Sciences, Madeira University, Campus

Universitário da Penteada, 9020-105 Funchal, Madeira, Portugal

e-mail: camire@uma.pt

J. Camacho

Laboratory Synlab Dr. Castro Fernandes, Rua do Hospital Velho 23A, 9060-129 Funchal, Portugal

e-mail: kamacho@gmail.com

R. Camacho

Freelancer Data Analyst, Funchal, Portugal

A. Góis · V. Nóbrega

Faculty of Engineering Sciences, Madeira University, Campus

Universitário da Penteada, 9020-105 Funchal, Madeira, Portugal

A. Góis

e-mail: agois@staff.uma.pt

V. Nóbrega

e-mail: vnobrega@staff.uma.pt gathered. Daily admissions at the emergency service due to CVD and markers levels for cardiac function were obtained from a public hospital. Exploratory and correlation analysis of all variables were performed, and the CVD relative risk (RR) of hospital admissions and mortality was calculated. During the study, mean annual concentrations of the air pollutants varied greatly, with $\mathrm{NO}_{x}$ and $\mathrm{O}_{3}$ showing the highest annual average concentrations. Two hundred ten thousand five hundred forty patients were admitted at the emergency service, $74 \%$ of them due to cardiovascular causes. Hospital admissions were positively correlated with $\mathrm{PM}_{2.5}$, and $\mathrm{SO}_{2}$. A positive and significant association between $\mathrm{PM}_{2.5}$ with creatine kinase myocardial band and B-type natriuretic peptides markers was found, whilst $\mathrm{SO}_{2}$ was positively associated with Creatine kinase myocardial band. The RR seemed to increased with $\mathrm{PM}_{2.5}$ and $\mathrm{NO}_{\mathrm{x}}$ exposure. Traffic-related pollutants were weakly but statistically associated to hospital admissions due to CVD and mortality. $\mathrm{PM}_{2.5}$ and $\mathrm{SO}_{2}$ were related with higher hospital admissions which in turn seemed to increase the serum markers. The risk of mortality was mainly associated with $\mathrm{O}_{3}$ and average air temperature. Adults and elders seem to be more susceptible to atmospheric pollutants, particularly in the winter.

Keywords Outdoor air pollutants · Cardiovascular diseases · Biomarkers · Hospital admissions · Madeira Island 


\section{Introduction}

Air pollution is considered an important environmental and social issue, posing multiple challenges in terms of management and mitigation of harmful pollutants (European Environment Agency 2016).

Outdoor air pollution in both urban and rural areas was estimated to cause 4.2 million premature deaths worldwide in 2016 (World Health Organization 2018). According to Cohen et al. (2017), ambient air pollution contributes substantially to the global burden of disease, which has increased over the past 25 years, as a result of both demographic and epidemiological trends and increasing levels of air pollution in low-income and middle-income countries.

As air quality declines, the risk of stroke, heart disease, lung cancer and chronic and acute respiratory diseases increases for the people exposed to air pollutants (Cohen et al. 2017, Haberzettl, 2018). Even at low dosage, outdoor and indoor air pollution is a recognized threat to human health, a fact that has been associated with increased morbidity and mortality worldwide (World Health Organization 2016).

From a health perspective, outdoor air pollution is a complex mixture of components which include airborne particulate matter $(\mathrm{PM})$ and the gaseous pollutants such as sulphur dioxide $\left(\mathrm{SO}_{2}\right)$ and nitrogen dioxide $\left(\mathrm{NO}_{2}\right)$, named primary pollutants. These pollutants are emitted directly into the air by combustion of fossil fuels whereas secondary pollutants like ozone $\left(\mathrm{O}_{3}\right)$ are formed in the atmosphere from other components. Outdoor air pollution (especially $\mathrm{PM}_{2.5}$ ) normally infiltrates buildings and most of the exposure typically occurs indoors (Newby et al. 2015).

According to Newby et al. (2015), air pollution shows substantial variability both between areas (higher in Southern Europe) and within areas. Spatial variation is mostly related to the presence of local and regional sources. Temporal variation of daily average air pollution concentrations is mostly related to weather conditions affecting the dispersion of pollutants, including wind direction, wind speed and atmospheric stability.

Scientific evidence from epidemiologic and experimental studies reported deleterious effects of short and long-term exposure to air pollutants on cardiovascular mortality. The most serious effects in terms of overall health impact include a significant reduction in the life expectancy of the average population of 1 year or more. Short-term exposure increases in air pollution were associated with an increased risk of myocardial infarction, stroke and acute heart failure (Bourdrel et al. 2017).

The inhalation of inorganic particles can increase cardiovascular diseases (CVDs) through pulmonary inflammation, inducing systemic blood coagulability (Franklin et al. 2015) and oxidative stress damage (Gagliardi et al. 2009, Strobel et al. 2011). Such exposure to air pollutants influences markers associated with increased risk of adverse cardiovascular events, like natriuretic peptides, while other serum markers can help diagnose, evaluate and control patients with suspected acute coronary syndrome, namely troponins, creatine kinase and creatine kinase-MB (myocardial band) (Bodor 2006).

As human exposure to air pollution became a sufficient condition for the onset of cardiovascular disease, the World Health Organisation (WHO), the Environmental Protection Agency and the European Commission (EC) have established guidelines for air quality risk assessment and management (World Health Organization 2016, United States Environmental Protection Agency 2018, European Commission Agency 2018).

Atmospheric pollutant levels often exceed established limits in various regions of the world, especially in large cities in developing countries. It was also noted that the adverse effect on human health has been documented at levels well below the official standards (Nebel and Wright 1993).

Coronary diseases are one of the main causes of death in Portugal (Instituto Nacional de Estatística 2014), though the occurrence of deaths due to CVD in relation to total mortality (34\%) is not as high as in other European Union (EU) countries which is $40 \%$ (Vasconcelos 2012). A previous national assessment on trends in heart failure showed that the number of patients for that condition has doubled between 2000 and 2015 (Moreira et al. 2017). Considering the ageing of the Portuguese population, it is expected a rise in the number of hospitalizations due to this ailment (Fonseca et al. 2018), as well as for other CVD.

In turn, Madeira has a high prevalence of CVD, namely stroke and myocardial infarction, with little epidemiological data about blood pressure (Macedo et al. 2010). On the other hand, the effects of exposure to outdoor air pollutants on cardiovascular health are still unknown.

The work aims to evaluate the influence of short-term exposure to atmospheric pollution in the occurrence of CVD and mortality due to CVD in Madeira region. For such purpose, a 7-year retrospective study was planned 
to explore the relationship between the main pollutants and the daily admissions at the emergency services due to CVD and markers levels for cardiac functions.

\subsection{Methods}

This is a single-centre retrospective study, conducted in Funchal city (Madeira Island, Portugal), between January 1, 2005, and December 31, 2011. Funchal is the most populous insular city in Portugal with a population of 105,117 inhabitants out of a total of 254,876 inhabitants in the Archipelago (Madeira em Números 2016), in which almost everyone lives in the coastal areas.

Air pollutants data were obtained from the Portuguese Environment Agency Air Quality Monitoring Network which gathers information from automated stations throughout Portugal. The three considered stations in Funchal were São João (traffic station), São Gonçalo and Quinta Magnólia (both urban type). The stations of Quinta Magnólia and São João are located at 0.52 and $0.55 \mathrm{~km}$ from the Hospital Centre, respectively, and the station in São Gonçalo is located at a distance of $3.9 \mathrm{~km}$ from this site. All stations provided hourly values of atmospheric pollutants, such as concentration of $\mathrm{PM}\left(\mathrm{PM}_{2.5}\right.$ and $\left.\mathrm{PM}_{10}\right)$, sulphur dioxide $\left(\mathrm{SO}_{2}\right)$, ozone $\left(\mathrm{O}_{3}\right)$ and nitrogen compounds $\left(\mathrm{NO}, \mathrm{NO}_{2}\right.$ and $\left.\mathrm{NO}_{\mathrm{x}}\right)$ and $\mathrm{O}_{3}$.

Meteorological data were obtained from the Portuguese Environment Agency website which provided daily data. The available parameters that could be related with the triggering of cardiovascular diseases were searched for the studied period, namely, average temperature $\left({ }^{\circ} \mathrm{C}\right)$, relative humidity (\%) and precipitation ( $\mathrm{mm})$.

Health data were obtained from a public hospital that provided daily counts of patients from any provenance within Madeira Archipelago that were admitted at the emergency service with suspected CVD. There was information on regards of gender and age groups as follows: less than 14 years old (children); 15-65 years old (adults) and over 65 years old (elders). The inhospital mortality due to CVD was also accessed.

From the symptoms recorded at the hospital emergency service, the ones that lead to the inclusion in the CVD diagnostic group were chest pain, headache and indisposition, as well as abnormal levels of selected serum markers of cardiac function: creatine kinase mass (CK), creatine kinase myocardial band (CK-MB), troponin (TP) and B-type natriuretic peptides (BNPs). All biochemical analyses were performed using an automated Beckman Coulter UniCel DxI 800 Immunoassay system. The reference values adopted by the hospital for the biochemical markers under study are shown on Table 1. This investigation was approved by the Hospital's Ethics Committee.

\subsection{Statistical Analysis}

For the statistical analysis, $\mathrm{PM}_{2.5}, \mathrm{PM}_{10}, \mathrm{SO}_{2}, \mathrm{O}_{3} \mathrm{NO}$, $\mathrm{NO}_{2}, \mathrm{NO}_{\mathrm{x}}$ concentrations and meteorological parameters were taken as independent variables whereas the daily number of hospitalisations for CVD for each age group was considered as dependent variables.

The effects of environmental pollution on health show a lag between the exposure of individuals to pollutants and their effects. The admissions observed on a specific day are related to the pollution of that day and to the pollution observed in the previous 3 days. Thus, moving averages of 3-day pollutants were used, which is the mean of the pollution of the day in question and the two previous days. This technique assigns equal weights to all days of the period, which leads to a certain distortion, by not allowing a diversification of the effect between the days of the interval (Schwartz 2004; Pope et al. 2008).

Relationship between atmospheric air pollutants, meteorological parameters, hospital admissions, mortality due to CVD and biochemical markers of cardiac function were searched for parametric (Spearman) correlations. Normality was tested using Shapiro-Wilk normality test.

The effects of air pollutants on the daily number of hospital admissions and deaths were estimated using Poisson-regression models. A multiple linear regression analysis involving more than two explanatory variables was applied, given by the following equation:

$\mathrm{y}=\beta_{0}+\beta_{1} \mathrm{x}_{1}+\ldots+\beta_{\mathrm{n}} \mathrm{x}_{\mathrm{n}}+\varepsilon$

where " $y$ " is the response variable (patients with CVD and mortality) and $x_{i}(i=1,2, \ldots, n)$ are the explanatory variables (concentration of pollutants, average temperature, precipitation and humidity). The $\beta_{0}$ is the value of $y$ when the explanatory variables are zero, the terms $\beta i$ are the regression coefficients and the residual $(\varepsilon)$ is the forecast error, i.e. the difference between the real and the expected values of the response variable (Tadano et al. 2009).

The relative risk (RR) of hospital admissions for CVD was estimated using the coefficients of the generalized linear Poisson regression models. The RR is given by the following equation: $\operatorname{RR}(x)=e^{\beta x}$, where 
Table 1 Descriptive analysis of the dependent and independent variables for the studied period

\begin{tabular}{|c|c|c|c|c|c|c|}
\hline \multicolumn{3}{|l|}{ Variables } & \multirow{2}{*}{$\frac{x}{9.07}$} & \multirow{2}{*}{$\frac{\text { Minimum }}{0.12}$} & \multirow{2}{*}{$\frac{\text { Maximum }}{35.68}$} & \multirow{2}{*}{$\frac{\mathrm{SD}}{5.99}$} \\
\hline Air pollutants & $24 \mathrm{~h}\left(\mu \mathrm{g} / \mathrm{m}^{3}\right)$ & $\mathrm{PM}_{2.5}$ & & & & \\
\hline & & $\mathrm{PM}_{10}$ & 24.97 & 5.53 & 54.28 & 9.74 \\
\hline & & $\mathrm{SO}_{2}$ & 2.39 & 0 & 11.76 & 1.73 \\
\hline & & $\mathrm{NO}$ & 16.00 & 0.46 & 62.51 & 15.78 \\
\hline & & $\mathrm{NO}_{2}$ & 25.36 & 0.54 & 63.52 & 15.70 \\
\hline & & $\mathrm{NO}_{\mathrm{x}}$ & 49.49 & 2.41 & 154.08 & 37.77 \\
\hline & & $\mathrm{O}_{3}$ & 44.62 & 12.85 & 78.76 & 13.54 \\
\hline \multirow[t]{4}{*}{ Number of general hospital admissions } & Total populatio & & 76.93 & 6 & 191 & 21.27 \\
\hline & $<14$ years old & & 14.51 & 0 & 76 & 9.35 \\
\hline & 15-65 years olc & & 40.71 & 0 & 103 & 12.89 \\
\hline & $>65$ years old & & 21.71 & 0 & 47 & 6.35 \\
\hline \multirow[t]{3}{*}{ Symptoms for CVD } & Headache & & 8.14 & 0 & 27 & 3.72 \\
\hline & Chest pain & & 15.52 & 0 & 53 & 9.39 \\
\hline & Indisposition & & 53.27 & 6 & 158 & 16.80 \\
\hline \multirow[t]{7}{*}{ Destiny of patients with CVD } & Number of disc & & 98.02 & 6 & 225 & 24.99 \\
\hline & Hospitalisation & VD & 1.35 & 0 & 7 & 1.29 \\
\hline & Number of dea & & 2.27 & 0 & 9 & 1.63 \\
\hline & Ratio males/fen & & 0.47 & 0.3 & 0.71 & 0.05 \\
\hline & Mean age & & 44.00 & 3 & 59.73 & 5.60 \\
\hline & Daily hospitalis & & 12.65 & 0 & 33 & 4.49 \\
\hline & Average hospit & ime in days & 8.72 & 0 & 69.38 & 3.72 \\
\hline
\end{tabular}

$e^{\beta x}$ is the exponential function of the regression coefficient of the pollutant multiplied by the pollutant concentration (Tadano et al. 2009).

Exploratory and correlation analysis were performed using Microsoft Excel software (version 2010), Statistica (version 7.0) and SPSS (version 20.0).

\section{Results}

The variation of mean air pollutants concentrations throughout the year for each air monitoring station in Funchal is shown in Fig. 1. The highest levels of $\mathrm{PM}, \mathrm{O}_{3}$ and nitrogen compounds were detected in São João station, whereas Quinta Magnólia station recorded the highest concentrations of $\mathrm{SO}_{2}$. $\mathrm{PM}$ levels were higher during the summer, mainly between July and September. $\mathrm{O}_{3}$ levels were constant throughout the year whereas $\mathrm{SO}_{2}$ showed several peaks along the year.

During the study period, a great variability of the mean annual concentrations of each air pollutant occurred (Table 1). $\mathrm{NO}_{\mathrm{x}}$ and $\mathrm{O}_{3}$ showed the highest annual average concentrations (49 and $45 \mu \mathrm{g} / \mathrm{m}^{3}$, respectively) and the highest maximum concentrations $\left(\mathrm{NO}_{\mathrm{x}} 154 \mu \mathrm{g} / \mathrm{m}^{3}\right.$ and $\left.\mathrm{O}_{3} 79 \mu \mathrm{g} / \mathrm{m}^{3}\right)$. In opposition, $\mathrm{SO}_{2}$ and $\mathrm{PM}_{2.5}$ had the lowest values ( 0 and $0.12 \mu \mathrm{g} / \mathrm{m}^{3}$, respectively). Overall, the annual average values peaked in 2006-2007 but revealed a decreasing trend in the following years (Fig. 2).

According to the EC standards, there were no exceedances of $\mathrm{SO}_{2}$ during the entire period of study, unlike $\mathrm{NO}_{2}$ and $\mathrm{PM}_{10}$ which showed the greatest number of daily exceedances per year (Fig. 3). There were $\mathrm{PM}_{10}$ values exceedances in all monitoring stations throughout the study period, mostly during the summer. In turn, $\mathrm{NO}_{2}$ values exceeded only in March of 2011 in São Gonçalo and in Quinta Magnólia. A total of 1096 (60\%) and 751 (41\%) days (60-41\% of all days) exceeded the daily legal limit for $\mathrm{NO}_{2}$ and $\mathrm{PM}_{10}$, respectively. Based on the $\mathrm{WHO}$ guidelines, the $\mathrm{PM}_{2.5}$ daily value of $25 \mu \mathrm{g} / \mathrm{m}^{3}$ was exceeded on 282 days (15\% of all days). 

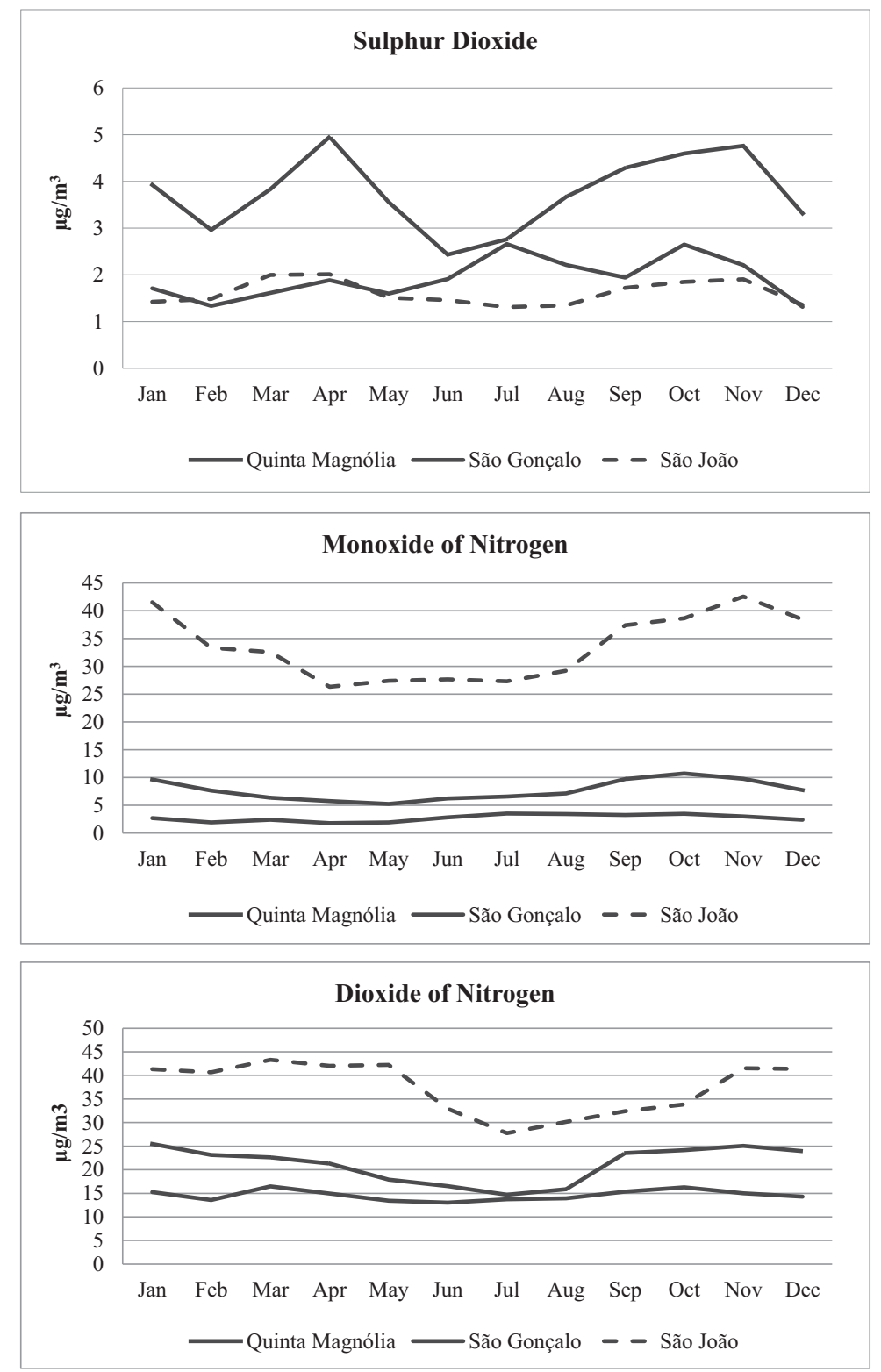

Fig. 1 a-g Monthly variations of PM and gaseous pollutants in Funchal. h Mean annual concentrations of each air pollutant (2005-2011)

\section{Analysis of Dependent Variables}

During the study, a total of 210,540 patients were admitted at the emergency service, from which $155,868(74 \%)$ were due to cardiovascular causes and $1.29 \%$ were hospitalized. The mean value of daily general admissions was higher in adults (40.7) followed by elderly patients (21.7) (Table 1 ). For the CVD patients, the mean age was 44 years and $53 \%$ of the patients were woman. The most frequent cause of hospitalization was indisposition $(n=107,942$;
$51.3 \%$ ), being the symptoms more frequent in female patients. Most of the hospitalizations were reported in the winter and fall of 2009 and the greatest hospitalization frequency for CVD was observed in the winters of all years. On average 77 daily admissions occurred due to CVD and a total of 4606 deaths were reported during the same study period.

The serum markers that attained maximum levels were $\mathrm{CK}$ and BNP, whilst those with the strongest patient ratio (m-male/f-female) were BNP, followed by CK-MB mass and CK (Tables 2 and 3). 

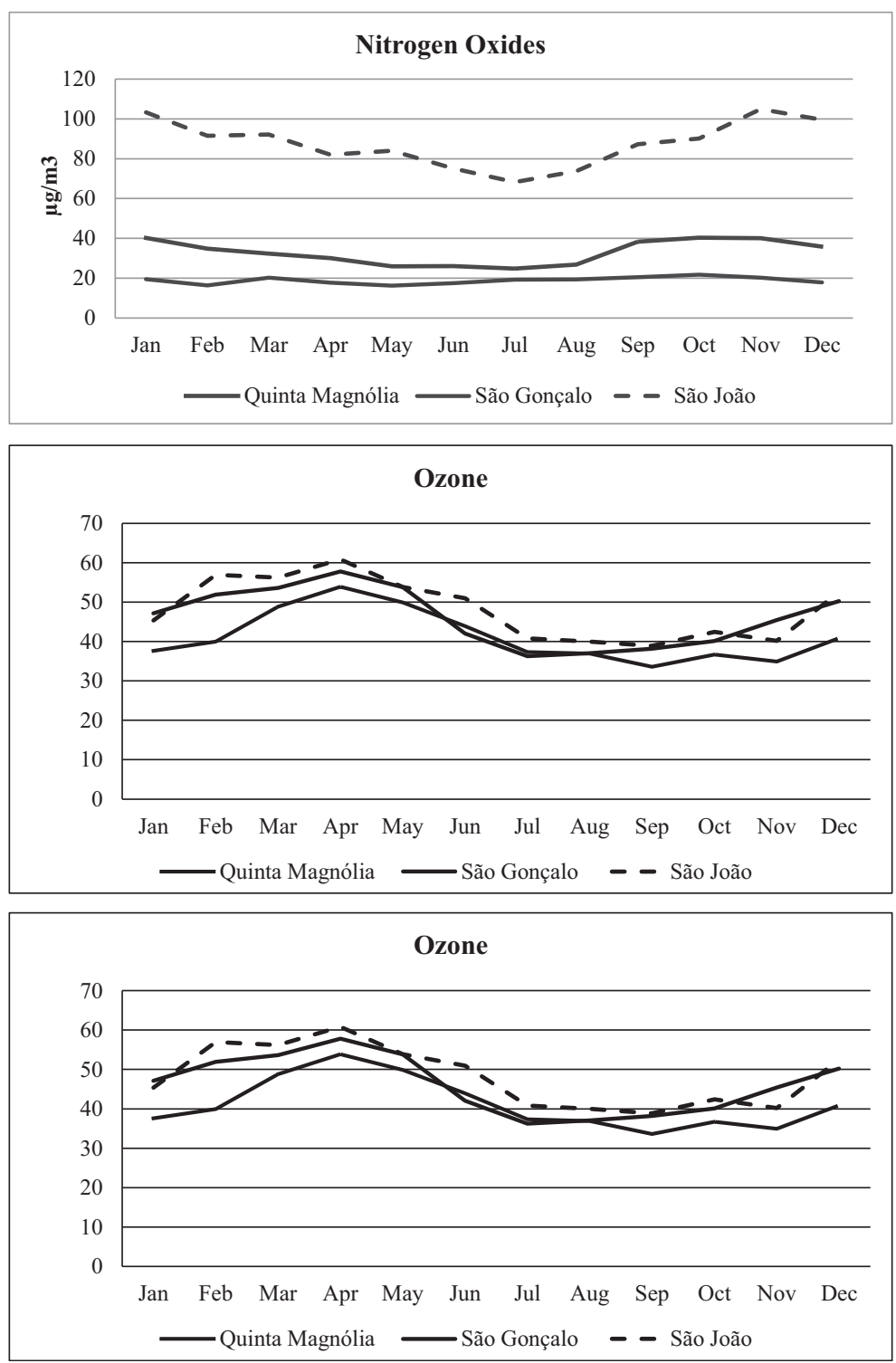

Fig. 1 (continued)

The overall correlation between morbility and air pollutants was weak. $\mathrm{PM}_{2.5}$ was strongly correlated with $\mathrm{PM}_{10}(r=0.68)$, and nitrogen compounds correlated with each other $(r=0.75,0.76$ and 0.77$)$, and with $\mathrm{O}_{3}$ $(r=0.50,0.55$ and 0.66$)$.

The total hospital admissions due to CVD were positively correlated with $\mathrm{PM}_{2.5}(r=0.12)$, and $\mathrm{SO}_{2}(r=$ $0.24)$, being hospital admissions in each age group positively associated with $\mathrm{SO}_{2}(r=0.13<r<0.24)$.

On regards to symptoms, indisposition was positively associated with $\mathrm{SO}_{2}$ and $\mathrm{NO}_{2}$ pollutants; on the other hand, all nitrogen compounds and $\mathrm{O}_{3}$ revealed positive association with headache.

In general, the mean temperature was positively correlated with $\mathrm{PM}_{2.5}$ and $\mathrm{PM}_{10}$, and inversely correlated with nitrogen compounds and $\mathrm{O}_{3}$.

As relative humidity increases, a significant decrease in $\mathrm{O}_{3}$ concentration occurred. Similarly, increases in precipitation was correlated to decreases of $\mathrm{PM}_{2.5}$, $\mathrm{PM}_{10}$, $\mathrm{NO}$ and $\mathrm{NO}_{2}$ pollutants.

Regarding molecular markers, a positive and significant association between $\mathrm{PM}_{2.5}$ with $\mathrm{CK}-\mathrm{MB}$ and $\mathrm{BNP}$ was 

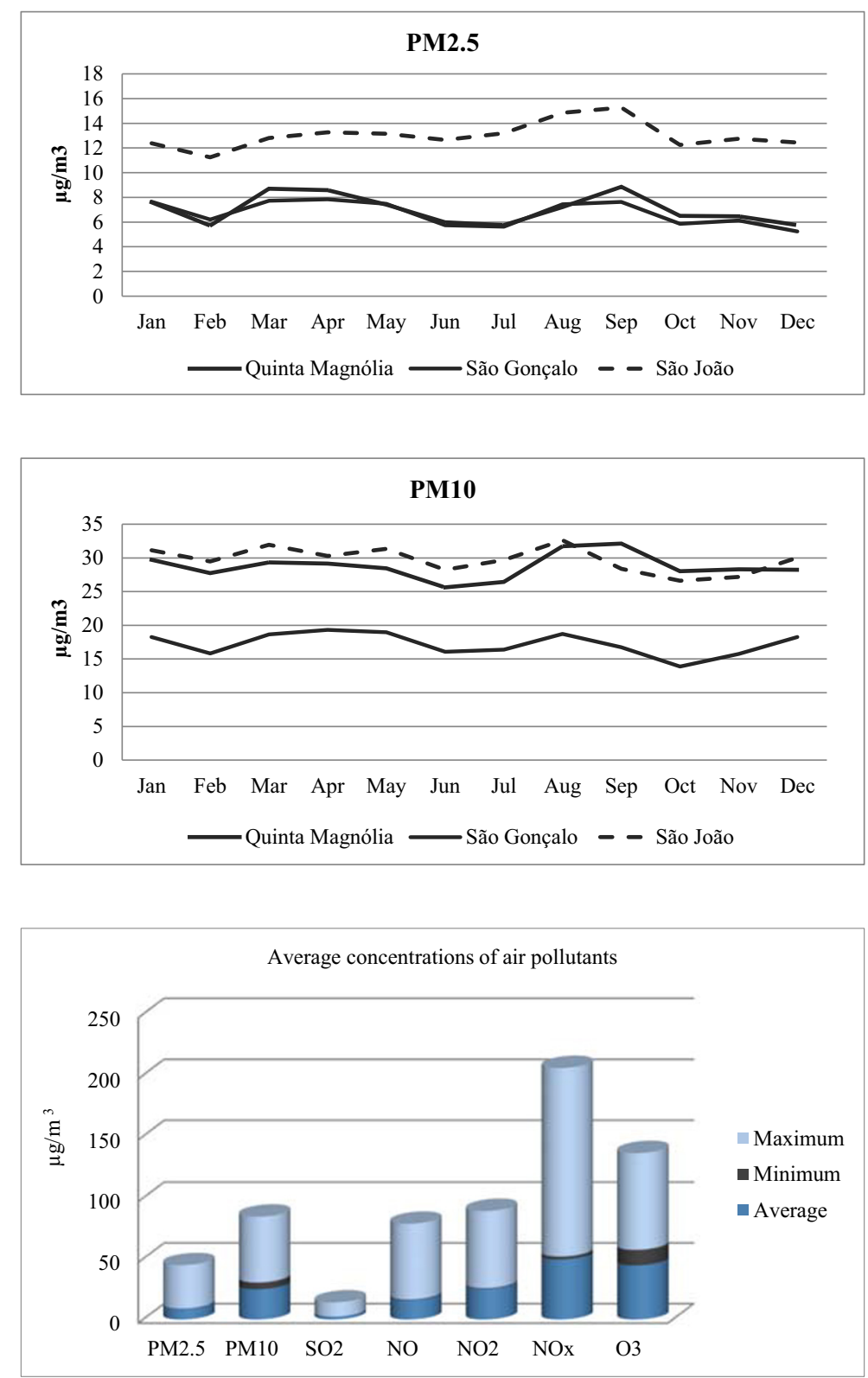

Fig. 1 (continued)

noted. Regarding $\mathrm{O}_{3}$, an association with TP and hospital admissions in adults and elderly patients was observed, but a negative association with the remaining serum markers.

Finally, there was a weak, though positive and statistically significant, correlation of mortality with $\mathrm{NO}$ and $\mathrm{NO}_{\mathrm{x}}$, whilst there was no association at all with $\mathrm{PM}_{2.5}$ and $\mathrm{SO}_{2}$.

The association of the dependent variables with meteorological parameters showed stronger correlation values (especially with mean temperature) than for the various air pollutants. Average temperature is inversely correlated with almost all variables, including mortality (Table 4). The application of regression model in order to assess the overall relation between the variables CVD and mortality with the explanatory variables resulted inconclusive. Notwithstanding, the Relative Risk of hospital admission due to CVD and mortality in result of short-term exposure to air pollutants are presented on Table 5. In sum, the RR increases with $\mathrm{PM}_{2.5}$ and $\mathrm{NO}_{\mathrm{x}}$ exposure, whereas the risk of mortality was mainly associated with $\mathrm{O}_{3}$ and average air temperature (Table 6). 
Fig. 2 Annual average concentrations of air pollutants monitored in Funchal during the studied period

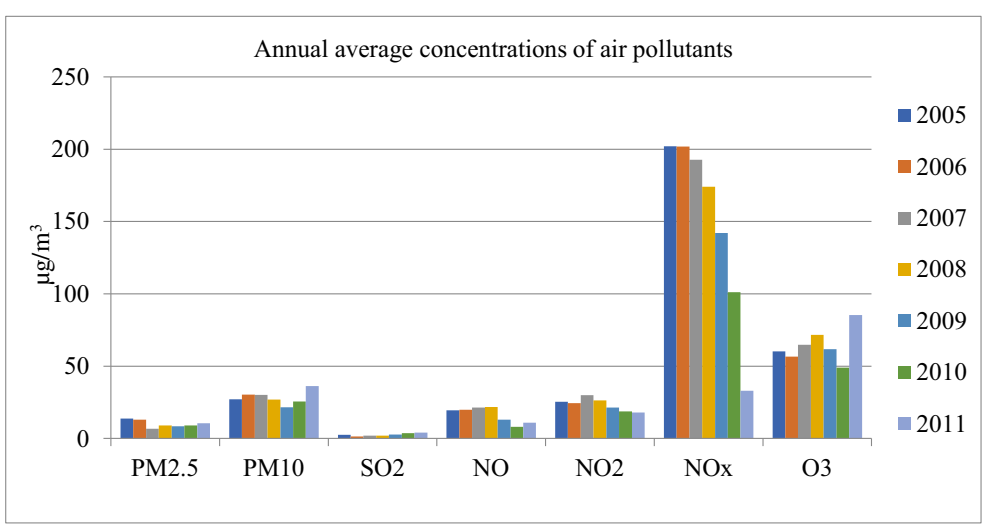

\section{Discussion}

This work estimates the short-term effects of air pollution in Funchal on morbidity and daily mortality due to CVD. Of the three monitoring stations under study, the traffic-type station of São João showed the highest levels of $\mathrm{PM}, \mathrm{O}_{3}$ and nitrogen compounds (Figs. 1 and 2). In fact, those air pollutants represent the main atmospheric contaminants in Europe, being frequently exceeded the limit values for suspended particles and nitrogen oxides in urban areas, where most of the population lives (Querol 2008).
Overall, the mean concentrations of all air pollutants decreased during the study period, except $\mathrm{PM}_{10}$ and $\mathrm{O}_{3}$ that revealed an increase in 2011 (Fig. 3). A downward trend in the annual air pollutant concentrations has been observed in other European countries (Querol et al. 2014), and by the European Environmental Agency during 1997-2010 (European Environment Agency 2013).

The majority of air pollutants produced in the urban area of Funchal derive from combustion processes, with traffic being their primary source. Yet, the traffic management measures implemented in the city over the last years could have a direct effect on air pollutant emission sources (Laboratório Regional de Engenharia Civil.

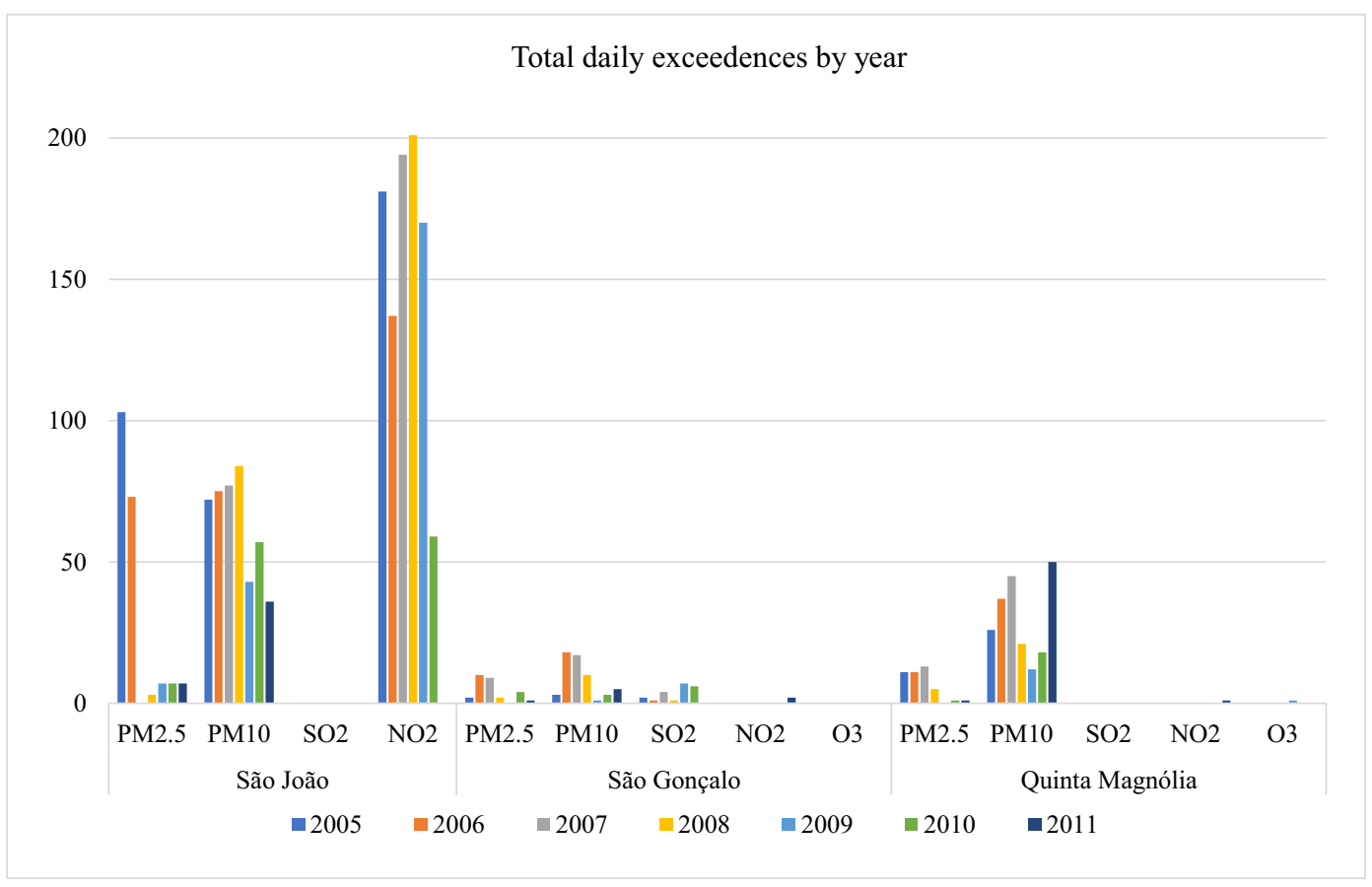

Fig. 3 Exceedances of air pollutants monitored in Funchal during the studied period 
Table 2 Descriptive analysis of serum markers for the studied period

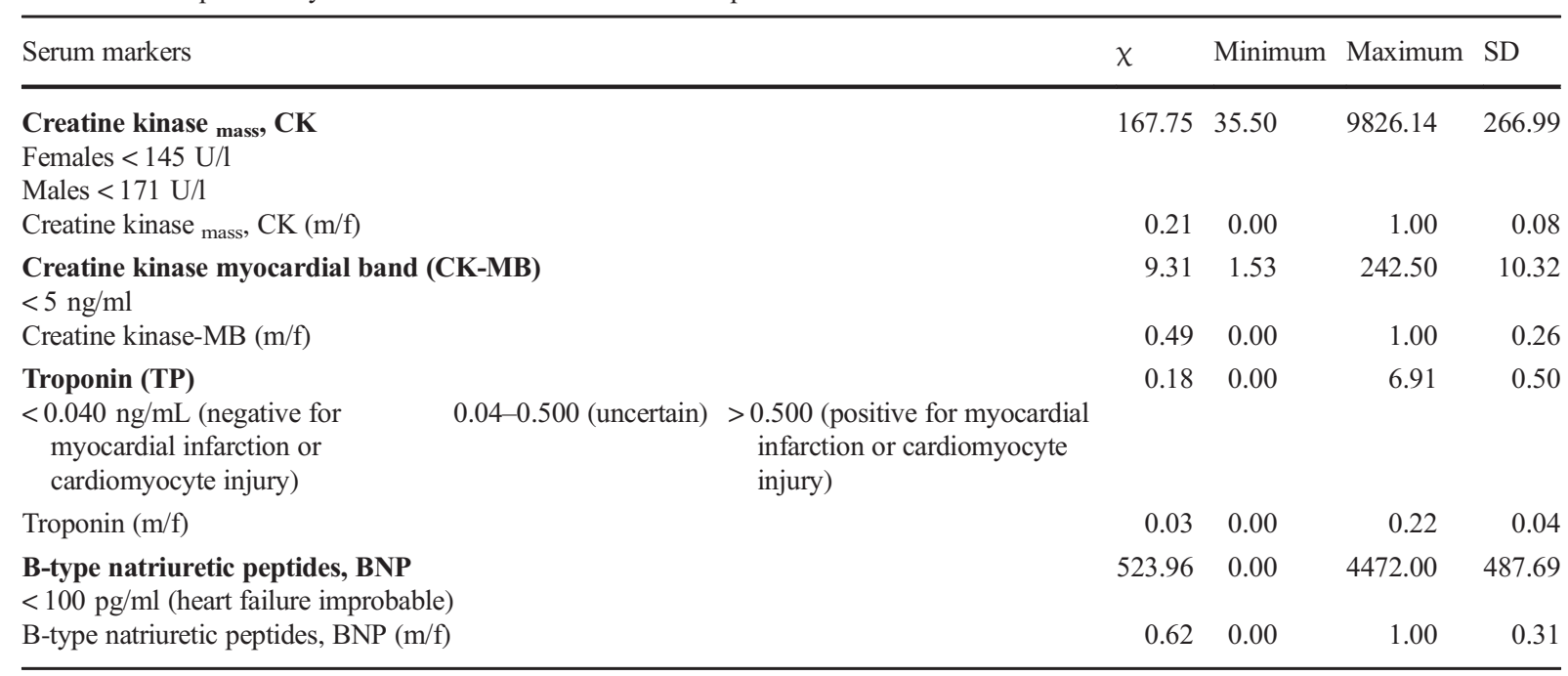

AREAM. Câmara Municipal do Funchal 1996). Furthermore, the urban architecture is characterized by low-rise buildings and several green spaces, particularities that favour the dispersion and dilution of air pollutants.

In this study, the levels of PM were higher during the summer, a fact also reported elsewhere (Liu et al. 2015), whereas $\mathrm{O}_{3}$ levels were constant throughout the year. The broad range of $\mathrm{O}_{3}$ levels might be explained by the constant annual radiation observed in Madeira, which in the presence of nitrogen oxides might lead to an increase in photochemical ozone production. Further, $\mathrm{O}_{3}$ concentrations are highest during the warmest high-intensity sunlight hours of the day, resulting in a significant human exposure (Newby et al. 2015).

A great variability in the mean annual concentrations of the atmospheric pollutants in Funchal occurred (Table 1), similarly to what was reported in other European cities. For instance, the $\mathrm{PM}_{10}$ annual average was $24.97 \mu \mathrm{g} / \mathrm{m}^{3}$, which is within the average values of 20 $25 \mu \mathrm{g} / \mathrm{m}^{3}$ observed in Europe since 2001 (Querol 2008).
On the other hand, $\mathrm{SO}_{2}$ revealed the minimum annual values during 2005-2011. $\mathrm{SO}_{2}$ is emitted when fuels containing sulphur are burned, being a major precursor of PM, which is associated with significant health effects. Considering the overall $\mathrm{SO}_{2}$ levels recorded in Funchal, its contribution on PM emissions at regional scale might be considered insignificant. In fact, the EU27 Member States have cut their $\mathrm{SO}_{\mathrm{x}}$ emissions by $50 \%$ during 2002-2011, leading to a fall in $\mathrm{SO}_{2}$ concentrations of about one third (Guerreiro et al. 2014). Moreover, $\mathrm{SO}_{2}$ levels were very low in most of Europe, a fact also reported in Madeira.

According to the EU standards, $\mathrm{NO}_{2}$ and $\mathrm{PM}$ revealed the greatest number of daily exceedances per year (Fig. 3); nevertheless, all nitrogen compounds had a downtrend, particularly after 2007. In contrast, a scenario of increasing trends of $\mathrm{NO}_{2}$ was reported in some stations of mainland Portugal, Poland and Luxembourg during 2002-2011 (Guerreiro et al. 2014). Accordingly, the ratio diesel/gasoline consumption for road transport has

Table 3 Age distribution, symptoms and serum biomarkers according to gender

\begin{tabular}{|c|c|c|c|c|c|c|c|c|c|}
\hline & \multicolumn{3}{|l|}{ Age classes } & \multicolumn{3}{|l|}{ Symptoms } & \multicolumn{3}{|c|}{ Biomarkers } \\
\hline & $\begin{array}{l}<14 \text { years } \\
\text { old }(22.5 \%)\end{array}$ & $\begin{array}{l}15-65 \text { years } \\
\text { old }(45.9 \%)\end{array}$ & $\begin{array}{l}>65 \text { years } \\
\text { old }(31.5 \%)\end{array}$ & Headache & Chest pain & Indisposition & $\mathrm{CK}$ & CK-MB & $\mathrm{BNP}$ \\
\hline Female & 20,819 & 51,573 & 39,631 & 9954 & 16,887 & 58,591 & 5956 & 3696 & 2285 \\
\hline Male & 26,610 & 45,117 & 26,783 & 6538 & 14,547 & 49,344 & 7144 & 4505 & 2805 \\
\hline
\end{tabular}


Table 4 Spearman rank correlation coefficients between all variables under study. $* p<0.05$

\begin{tabular}{|c|c|c|c|c|c|c|c|}
\hline & $\mathrm{PM}_{2.5}$ & $\mathrm{PM}_{10}$ & $\mathrm{SO}_{2}$ & $\mathrm{NO}$ & $\mathrm{NO}_{2}$ & $\mathrm{NO}_{\mathrm{x}}$ & $\mathrm{O}_{3}$ \\
\hline $\mathrm{PM}_{2.5}(24 \mathrm{~h})$ & 1.00 & & & & & & \\
\hline $\mathrm{PM}_{10}(24 \mathrm{~h})$ & $0.68^{*}$ & 1.00 & & & & & \\
\hline $\mathrm{SO}_{2}(24 \mathrm{~h})$ & 0.29 & 0.25 & 1.00 & & & & \\
\hline NO (24 h) & 0.30 & 0.35 & 0.15 & 1.00 & & & \\
\hline $\mathrm{NO}_{2}(24 \mathrm{~h})$ & 0.26 & 0.29 & 0.32 & $0.75^{*}$ & 1.00 & & \\
\hline $\mathrm{NO}_{\mathrm{x}}(24 \mathrm{~h})$ & 0.33 & 0.27 & & $0.76^{*}$ & $0.77 *$ & 1.00 & \\
\hline $\mathrm{O}_{3}(24 \mathrm{~h})$ & 0.05 & 0.16 & & $0.66^{*}$ & $0.50 *$ & $0.55^{*}$ & 1.00 \\
\hline Hospital admissions due to CVD (total) & $0.12^{*}$ & -0.07 & $0.24 *$ & -0.06 & 0.08 & & 0.06 \\
\hline Hospital admissions due to CVD on children & & & $0.16^{*}$ & -0.06 & 0.06 & 0.06 & -0.08 \\
\hline Hospital admissions due to CVD on adults & $0.11 *$ & $-0.12^{*}$ & $0.20^{*}$ & & 0.05 & & $0.10^{*}$ \\
\hline Hospital admissions due to CVD on elderly & $0.15^{*}$ & & $0.13^{*}$ & & 0.07 & & $0.12 *$ \\
\hline Headache & & & & $0.17^{*}$ & $0.15^{*}$ & $0.15^{*}$ & $0.16^{*}$ \\
\hline Chest pain & $0.21^{*}$ & $-0.11^{*}$ & 0.09 & & -0.05 & & $0.12 *$ \\
\hline Indisposition & & & $0.25^{*}$ & -0.08 & $0.12 *$ & & \\
\hline Number of discharges & 0.08 & -0.07 & $0.22 *$ & & $0.11 *$ & 0.07 & $0.11 *$ \\
\hline Number of deaths & & 0.09 & & $0.10^{*}$ & 0.09 & $0.12 *$ & 0.07 \\
\hline Ratio males/females (m/f) & & & & & & & -0.06 \\
\hline Average age & 0.05 & & $-0.10^{*}$ & & & -0.08 & 0.08 \\
\hline Daily hospitalisation counts & $0.12 *$ & $0.10 *$ & & $0.10^{*}$ & $0.10 *$ & $0.12 *$ & 0.08 \\
\hline Average hospitalisation time in days & 0.05 & 0.09 & -0.06 & $0.11 *$ & $0.10 *$ & $0.14^{*}$ & \\
\hline Average temperature & $0.14^{*}$ & $0.23 *$ & 0.08 & $-0.20 *$ & -0.08 & $-0.30 *$ & $-0.26^{*}$ \\
\hline Humidity & & & & & 0.07 & -0.07 & $-0.16^{*}$ \\
\hline Precipitation & $-0.11 *$ & $-0.18^{*}$ & & -0.06 & -0.07 & & \\
\hline Creatine kinase, $\mathrm{CK}$ & 0.06 & & -0.05 & & & 0.07 & \\
\hline Creatine kinase, CK (m/f) & 0.06 & & -0.04 & & & & \\
\hline Creatine kinase-MB mass & $0.13^{*}$ & -0.07 & $0.19 *$ & $-0.36^{*}$ & $-0.23 *$ & $-0.30 *$ & $-0.29 *$ \\
\hline Creatine kinase-MB mass $(\mathrm{m} / \mathrm{f})$ & $0.10 *$ & & $0.15^{*}$ & $-0.34 *$ & $-0.20 *$ & $-0.25^{*}$ & $-0.30^{*}$ \\
\hline Troponin & 0.08 & -0.07 & & & $-0.11 *$ & -0.07 & $0.10^{*}$ \\
\hline Troponin $(\mathrm{m} / \mathrm{f})$ & & & & & -0.08 & $-0.10^{*}$ & \\
\hline B-type natriuretic peptides, BNP & $0.14^{*}$ & $-0.15^{*}$ & 0.09 & $-0.15^{*}$ & $-0.19^{*}$ & $-0.16^{*}$ & -0.07 \\
\hline B-type natriuretic peptides, BNP (m/f) & $0.15^{*}$ & $-0.17^{*}$ & & $-0.13^{*}$ & $-0.17 *$ & $-0.11 *$ & \\
\hline Mortality & & 0.09 & & $0.10^{*}$ & 0.09 & $0.12 *$ & 0.07 \\
\hline
\end{tabular}

almost doubled during that time, increasing the $\mathrm{NO}_{2}$ concentrations at Portuguese stations.

On regards to $\mathrm{PM}$, the inhalation of these particles can trigger adverse cardiovascular responses remotly from the site of deposition within pulmonary tissues. These include an increase in the systemic circulation of pro-inflammatory or oxidative stress mediators generated in the lungs; the instigation of autonomic nervous system imbalance and the penetration of certain particles or components directly into cardiovascular tissues. These pathways may be activated at different time frames and vary accordingly to exposure duration and dosage, and by inhaled particulate sizes or components (Franklin et al. 2015).

In all monitoring stations in Funchal, primary compounds like $\mathrm{PM}_{10}$ and $\mathrm{PM}_{2.5}$ exceed emission limits set under EU legislation, especially in São João, attaining 472 and 209 days of exceedances, respectively. During 2002-2011, 20 to 44\% of the EU-27 urban population was exposed to concentrations of $\mathrm{PM}_{10}$ in excess of the EU air quality daily limit amount, despite the emission reductions. In addition, $31 \%$ of the EU-27 urban 
Table 5 Spearman rank correlation coefficients between all variables studied and the meteorological parameters. $* p<0.05$

\begin{tabular}{|c|c|c|c|}
\hline Dependent variables & Mean temperature & Humidity & Precipitation \\
\hline Hospital admissions due to CVD (Total) & $-0.33^{*}$ & & \\
\hline Hospital admissions due to CVD on children & $-0.33 *$ & & \\
\hline Hospital admissions due to CVD on adults & $-0.22 *$ & & \\
\hline Hospital admissions due to CVD on elderly & $-0.12^{*}$ & & \\
\hline Headache & $-0.14 *$ & & \\
\hline Chest pain & $-0.15^{*}$ & & 0.09 \\
\hline Indisposition & $-0.30^{*}$ & & \\
\hline Number of discharges & $-0.44 *$ & -0.07 & 0.07 \\
\hline Number of deaths & $-0.11 *$ & & \\
\hline Daily hospitalization counts & $-0.19 *$ & & \\
\hline Average hospitalization time in days & & & -0.08 \\
\hline Creatine kinase, $\mathrm{CK}$ & -0.06 & & \\
\hline \multicolumn{4}{|l|}{ Creatine kinase, $\mathrm{CK}$ (m/f) } \\
\hline Creatine kinase-MB mass & $-0.18^{*}$ & -0.09 & $0.11 *$ \\
\hline Creatine kinase-MB mass (m/f) & $-0.31 *$ & $-0.12 *$ & \\
\hline Troponin, TP & $-0.17^{*}$ & & \\
\hline Troponin, TP (m/f) & -0.09 & & \\
\hline B-type natriuretic peptides, BNP & $-0.21 *$ & & \\
\hline B-type natriuretic peptides, BNP (m/f) & $-0.23^{*}$ & & \\
\hline Mortality & $-0.12 *$ & & \\
\hline
\end{tabular}

population was exposed to $\mathrm{PM}_{2.5}$ levels above the exposure concentration limits and $96 \%$ was exposed to levels above the WHO standards in 2011 (Guerreiro et al. 2014).

Most of patients admitted at the emergency service (74\%) were due to cardiovascular causes, being the majority adults and women (53\%). The biomarkers with the strongest patient ratio $(\mathrm{m} / \mathrm{f})$ were $\mathrm{BNP}$, followed by CK-MB mass and CK. In general, women are less likely to have cardiovascular comorbidities, presenting different biomarker profiles and different diagnostic spectrum comparatively to men. Cardiac biomarkers including TP, myoglobin, CK and natriuretic-proBNP are lower in women, which is consistent with a lower rate of acute coronary syndromes (Stähli et al. 2015, Shah et al. 2017). There are also gender differences in CK-MB concentrations and evidences that females had significantly lower levels than males among apparently

Table 6 Relative risk (RR) of hospital admissions due to CVD

\begin{tabular}{|c|c|c|c|c|c|c|}
\hline Variables/RR & $\mathrm{B}$ & SE & Wald & $d f$ & Sig. & $\operatorname{Exp}(B)$ \\
\hline $\mathrm{PM}_{2.5}$ & 0.025 & 0.006 & 20.54 & 1 & 0.000 & 1.026 \\
\hline $\mathrm{PM}_{10}$ & -0.008 & 0.002 & 12.324 & 1 & 0.000 & 0.992 \\
\hline $\mathrm{NO}_{2}$ & -0.014 & 0.005 & 8.257 & 1 & 0.004 & 0.986 \\
\hline $\mathrm{NO}_{\mathrm{x}}$ & 0.005 & 0.001 & 50.431 & 1 & 0.000 & 1.005 \\
\hline $\mathrm{O}_{3}$ & -0.007 & 0.002 & 9.387 & 1 & 0.002 & 0.993 \\
\hline Mean temperature & 0.020 & 0.01 & 3.927 & 1 & 0.048 & 1.02 \\
\hline \multicolumn{7}{|l|}{ RR of mortality } \\
\hline $\mathrm{O}_{3}$ & 0.004 & 0.002 & 4.144 & 1 & 0.042 & 1.004 \\
\hline Mean temperature & 0.018 & 0.008 & 5.148 & 1 & 0.023 & 1.018 \\
\hline
\end{tabular}


healthy subjects. Such differences were attributed probably due to a greater skeletal mass in men (Shah et al. 2017, Strunz et al. 2011).

The overall correlation between morbidity and air pollutants showed that $\mathrm{PM}_{2.5}$ was strongly correlated with $\mathrm{PM}_{10}(r=0.68)$, nitrogen compounds correlated with each other $(r=0.75,0.76$ and 0.77$)$, and with $\mathrm{O}_{3}$ $(r=0.50,0.55$ and 0.66$)$. A similar, though moderate, correlation between $\mathrm{NO}_{2}$ and $\mathrm{O}_{3}$ was found in Lisbon between 1999 and 2004 (Freitas et al. 2010). Also, the total hospital admissions in Funchal due to CVD were positively correlated with $\mathrm{PM}_{2.5}(r=0.12)$, and $\mathrm{SO}_{2}$ $(r=0.24)$, while hospital admissions were positively associated with $\mathrm{SO}_{2}(r=0.13<r<0.24)$ in all age groups. A multicenter European study suggested that $\mathrm{SO}_{2}$ pollution may play an independent role in triggering ischemic cardiac events (Sunyer et al. 2003). Accordingly, the daily numbers of all cardiovascular admissions except stroke, and particularly ischemic heart diseases, rose significantly with an increase of daily $\mathrm{SO}_{2}$ levels in the same day and the day before.

Our results revealed that the dependent variables and meteorological parameters showed strong correlation, especially with average air temperature. Previous findings showed association between the outside air temperature and deaths by CVD (Analitis et al. 2008; Pinheiro et al. 2014). Hsu et al. (2017) reported stronger effects on CVD hospitalizations in winter and at low temperature days. According to Wilson et al. (2010), the myocardium needs greater oxygenation when the body registers a cooling, especially in the elderly population, thus triggering a risk of cardiac complications associated with cold sensation.

In Funchal, the greatest hospitalization frequency for CVD was observed in the winter of all years. In elder patients higher temperatures were associated with fewer hospitals admissions, while in the other age groups, it seems to induce admissions at an enhanced rate. These findings were in accordance with Freitas et al. (2010), which supports that the age of the population does influence circulatory conditions, not only in association with temperature but also with $\mathrm{SO}_{2}$ pollutants. Also, the proportion of deaths from CVD increases with age in Europe and CVD is a less common cause of death in younger ages (Townsend et al. 2015), a fact also reported in our study.

On regards to symptoms, indisposition seems positively associated with $\mathrm{SO}_{2}$ and $\mathrm{NO}_{2}$ pollutants, while all nitrogen compounds and $\mathrm{O}_{3}$ were statistically associated with headache. Our data suggests that air pollution could be associated with short-term health effects, even in areas with low pollutant concentrations like Madeira. Despite the current clean air regulations and a general trend towards a better air quality, the daily levels of air pollutants seem to trigger medical emergencies.

In Funchal, the mean temperature was positively correlated with PM and inversely correlated with nitrogen compounds $\left(\mathrm{NO}, \mathrm{NO}_{2}\right)$ and $\mathrm{O}_{3}$. There are evidences that weather condition is a major driving force of air pollution: higher temperature speeds up chemical reactions in the air, while lower temperature makes the PM dissipate in the air more slowly than usual. Jayamurugan et al. (2013) reported that $\mathrm{SO}_{2}$ and $\mathrm{NO}_{\mathrm{x}}$ were negatively correlated with temperature during the summer in Chennai (India). It is believed that the influence of temperature on $\mathrm{NO}_{\mathrm{x}}$ is much more effective in summer than in other seasons due to the higher temperature range.

In Funchal, as relative humidity increases, a decrease in $\mathrm{O}_{3}$ concentration seemed to occur. Similarly, increases in precipitation are related with significant decreases of PM, a finding also observed by Katsouyanni et al. (2001). Rainfall washes out water-soluble pollutants and PM (Hsu et al. 2017), whereas relative humidity appears to boost hospital admissions due to circulatory conditions (Azevedo et al. 2011).

Finally, there was a weak, though positive and significant, correlation of mortality with $\mathrm{NO}$ and NOx, and no association at all with $\mathrm{PM}_{2.5}$ and $\mathrm{SO}_{2}$. Conversely, in the Canary Islands, a positive association between the two fractions of PM and mortality from heart disease during the period 2000-2004 was found (López et al. 2010). There are evidences that the peculiarities of such islands have a significant effect on the origin and composition of the particulate matter, namely the influence of local pollution sources and the influence of African air mass intrusions.

The relative risk of hospital admission due to CVD and mortality in sequence of short-term exposure to air pollutants revealed an increase after $\mathrm{PM}_{2.5}$ and $\mathrm{NO}_{\mathrm{x}}$ exposure. Further, the risk of mortality was apparently associated with $\mathrm{O}_{3}$ and average air temperature. Several single-city and multicity studies reported an increased mortality risk associated with short-term exposure to $\mathrm{PM}, \mathrm{NO}_{2}$ and $\mathrm{O}_{3}$. There is compelling evidence that exposure to air pollution, especially short-term changes in PM and associated pollutants, contribute to CVD and death (Newby et al. 2015, Franklin et al. 2015). Shortterm exposures to PM are associated with subclinical adverse markers related to CVD, including systemic 
inflammation, vascular or endothelial dysfunction, increased endothelial cell activation and blood coagulation (Franklin et al. 2015). Exposure to traffic, particularly $\mathrm{PM}_{2.5}$, may increase blood pressure, exacerbate myocardial ischemia (Brook et al. 2009, Mills et al. 2009) and trigger myocardial infarction within hoursto-days (Peters et al. 2013, Rich et al. 2010).

This risk of CVD appears to vary in a linear manner with PM levels, without evidence of a safe PM threshold, even down to levels $<3-5 \mu \mathrm{g} / \mathrm{m}^{3}$ (Dominici et al. 2003). The risk of myocardial infarctions has been shown to increase by $48 \%$ following exposure of only a 2-h-long increase of $\mathrm{PM}_{2.5}$ by $25 \mu \mathrm{g} / \mathrm{m}^{3}$ (Peters et al. 2001). More, heart attack risk may be increased 2.73fold only $1 \mathrm{~h}$ after exposure to traffic (Peters 2005).

According to Bourdrel et al. (2017), short-term increases in air pollution were associated with an increased risk of stroke and acute heart failure, and the risk was still increased at pollution levels below current European air quality standards. The $\mathrm{NO}_{2}$ exposure related risk seems to be greater among our younger patients. Short-term increases in gaseous compounds, such as $\mathrm{NO}_{2}, \mathrm{SO}_{2}$ and $\mathrm{CO}$, also increased the risk of stroke. Studies examining short-term variations of $\mathrm{NO}_{2}$ reported an increase in cardiovascular mortality of $0.4-0.88 \%$ for a $10 \mu \mathrm{g} / \mathrm{m}^{3}$ daily increase of $\mathrm{NO}_{2}$ (Bourdrel et al. 2017).

Our survey showed a positive and significant association of $\mathrm{PM}_{2.5}$ with $\mathrm{CK}-\mathrm{MB}$ mass and $\mathrm{BNP}$, and a positive association between $\mathrm{SO}_{2}$ and $\mathrm{CK}-\mathrm{MB}$ mass. Our results suggest that $\mathrm{PM}_{2.5}$ and $\mathrm{SO}_{2}$ were associated with the total hospital admissions due to CVD, which probably induced a short-term response of certain cardiac markers. CK-MB mass is considered the 'gold standard' for acute myocardial infarction diagnosis in humans (Archer 2003), being detectable 3-4 h after myocardial injury (Brame and Childers 2011). In turn, BNP is considered a strong predictor for the diagnosis of heart failure and correlations have been made between the degree of BNP increase and the extent of myocardial ischemia (Brame and Childers 2011). A rise of BNP blood level is very fast, in the order of minutes to tens of minutes (Bartoš et al. 2016).

Other works reported an increased risk of stroke after a short-term elevation of $\mathrm{O}_{3}$, and out-of-hospital cardiac arrest. $\mathrm{O}_{3}$ was also associated with acute coronary events in middle-aged adults with no preexisting CVD (Bourdrel et al. 2017), while several other short time series studies evidenced an association between $\mathrm{O}_{3}$ and mortality (López-Villarrubia et al. 2010), consistently with our results.
This study revealed an association between $\mathrm{O}_{3}$, TP and hospital admissions in adults and elderly patients. Increases in cardiac TP can be seen as early as 2 to $4 \mathrm{~h}$ after myocardial injury (Brame and Childers, 2011), being correlated to the extent of myocardial damage (Archer 2003). Previous reports demonstrated that TP appears in the serum $4-10 \mathrm{~h}$ after the onset of acute myocardial infarction but the sensitivity for detecting TP approaches $100 \%$ when sampled 6-12 h after acute chest pain onset. Therefore, in that context patients need to repeat the TP sampling 6-12 $\mathrm{h}$ after the initial assessment (Garg et al. 2017).

\section{Limitations of the Study}

This prospective study revealed several limitations due to the original dataset structure. There was a lack of registration of symptom onset time and blood harvesting time for biochemical analysis. Also, the absence of air pollution data for the period 2012-2014 limited the extent of our study. Hence, the influence of atmospheric pollutants in the serum markers and mortality could be more consistent with larger data sets.

The population data did not include information such as medication intake, smoking history, hypertension, previous coronary events or CVD family history. Several medical conditions might increase serum TP levels due to non-cardiac causes. Also, elevated CK and CKMB may occur in non-cardiac conditions, and medium increased concentrations of BNP might indicate clinical condition of renal failure or others.

We were not able to assess the serial measurements of each cardiac marker in order to reliably rule out any specific cardiac event.

Our findings are in line with existing epidemiological evidences, although the magnitude of the estimated risk is lower in comparison with multicenter studies conducted in larger cities.

\section{Conclusions}

We observed associations of traffic-related pollutants on hospital admissions due to CVD and mortality, notwithstanding the low magnitude of such associations. $\mathrm{PM}_{2.5}$ and $\mathrm{SO}_{2}$ pollutants were apparently related with higher hospital admissions which in turn seemed to increase the cardiac markers. In addition, our results showed that the 
risk of hospital admission due to CVD seemed to increase not only with $\mathrm{PM}_{2.5}$ but also with $\mathrm{NO}_{\mathrm{x}}$ pollutants. In turn, the risk of mortality was mainly associated with $\mathrm{O}_{3}$ and average air temperature. Adults and elders seem to be more susceptible to atmospheric pollutants, particularly in the winter.

Acknowledgements A special thank to SESARAM's Administration, to Dr. Fátima Teixeira, Dr. Ilídio Ornelas from the Hospital Dr. Nélio Mendonça, and also to Dr. Mónica Fernandez for the assistance in the statistical analysis. The authors are grateful to Doctor Cristiana Granito Camacho from the Hospital Dr. Nélio Mendonça for the proof reading and valuable comments.

\section{Compliance with Ethical Standards}

Conflict of Interests The authors declare that they have no conflict of interest.

\section{References}

Analitis, A., Katsouyanni, K., Biggeri, A., Baccini, M., Forsberg, B., \& Bisanti, L. (2008). Effects of cold weather on mortality: Results from 15 European cities within the PHEWE project. American Journal of Epidemiology, 168(12), 1397-1408.

Archer, J. (2003). Cardiac biomarkers: A review. Comparative Clinical Pathology, 12(3), 121-128.

Azevedo, J. M., Gonçalves, F. T., \& Andrade, M. F. (2011). Longrange ozone transport and its impact on respiratory and cardiovascular health in the north of Portugal. International Journal of Biometeorology, 55, 187-202.

Bartoš, V., Dastych, M., Dastych, M., Franek, T., Jirsa, M., Kalousová, M., et al. (2016). Clinical biochemistry (1st ed.). Prague: Karolinum Press.

Bodor, G. S. (2016). Biochemical markers of myocardial damage. Electronic Journal of the International Federation of Clinical Chemistry and Laboratory Medicine, 27(2), 95-111.

Bourdrel, T., Bind, M. A., Béjot, Y., Morel, O., \& Argacha, J. (2017). Cardiovascular effects of air pollution. Archives of Cardiovascular Diseases, 110(11), 634-642.

Brame, G. R., \& Childers Jr., W. A. (2011). Cardiac biomarkers: Current standards, future trends. Clinician Reviews, 21(10), 30-35.

Brook, R. D., Urch, B., Dvonch, J. T., Bard, R. L., Speck, M., Keeler, G., et al. (2009). Insights into the mechanisms and mediators of the effects of air pollution exposure on blood pressure and vascular function in healthy humans. Hypertension, 54, 659-667.

Cohen, A. J., Brauer, M., Burnett, R., Anderson, H., Frostad, J., Estep, K., et al. (2017). Estimates and 25-year trends of the global burden of disease attributable to ambient air pollution: An analysis of data from the Global Burden of Diseases Study 2015. Lancet, 389(10082), 1907-1918.
Dominici, F., McDermott, A., Zeger, S. L., \& Samet, J. M. (2003). National maps of the effects of particulate matter on mortality: Exploring geographical variation. Environmental Health Perspectives, 111(1), 39-44.

European Environment Agency. (2013). Air quality in Europe 2013 report (pp. 1-112). Luxembourg: Publications Office of the European Union, $\mathrm{n}^{\circ}$ 9. https://www.eea.europa. eu/publications/air-quality-in-europe-2013. Accessed 10 Mar 2018.

European Environment Agency. (2016). Air quality in Europe 2016 report (pp. 1-88). Luxembourg: Publications Office of the European Union, $n^{\circ} 28$. https://www.eea.europa. $\mathrm{eu} /$ publications/air-quality-in-europe-2016. Accessed 10 Mar 2018.

European Commission Agency (2018). Air Quality Standards. http://ec.europa.eu/environment/air/quality/standards.html. Accessed 20 August 2018.

Fonseca, C., Brás, D., Araújo, I., \& Ceia, F. (2018). Heart failure in numbers: Estimates for the 21st century in Portugal. Revista Portuguesa de Cardiologia, 37(2), 97-104.

Franklin, B. A., Brook, R., \& Pope, C. A. (2015). Air pollution and cardiovascular disease. Current Problems in Cardiology, 40(5), 207-238.

Freitas, M. C., Pacheco, A. M., Verburg, T. G., \& Wolterbeek, H. T. (2010). Effect of particulate matter, atmospheric gases, temperature, and humidity on respiratory and circulatory diseases' trends in Lisbon, Portugal. Environmental Monitoring and Assessment, 162(1-4), 113-121.

Gagliardi, A. C., Miname, M. H., \& Santos, R. D. (2009). Uric acid: A marker of increased cardiovascular risk. Atherosclerosis, 202(1), 11-17.

Garg, P., Morris, P., Fazlanie, A. L., Vijayan, S., Dancso, B., Dastidar, A. G., et al. (2017). Cardiac biomarkers of acute coronary syndrome: From history to high-sensitivity cardiac troponin. Internal and Emergency Medicine, 12(2), 147-155.

Guerreiro, C. B., Foltescu, V., \& Leeuw, F. (2014). Air quality status and trends in Europe. Atmospheric Environment, 98, 376-384.

Haberzettl, P. (2018). Circadian toxicity of environmental pollution. Inhalation of polluted air to give a precedente. Current Opinion in Physiology, 5, 16-24.

Hsu, W. H., Hwang, S. A., Kinney, P. L., \& Lin, S. (2017). Seasonal and temperature modifications of the association between fine particulate air pollution and cardiovascular hospitalization in New York state. Science of the Total Environment, 578, 626-632.

Instituto Nacional de Estatística (2014). Risco de Morrer 2012. https://www.ine.pt/xportal/xmain?xpid=INE\&xpgid=ine publicacoes \&PUBLICACOESpub boui $=21638239 \overline{3}$ $\&$ PUBLICACOESmodo $=2 \&$ xlang $=$ pt. Accessed 18 August 2018.

Jayamurugan, R., Kumaravel, B., Palanivelraja, S., \& Chockalingam, M. P. (2013). Influence of temperature, relative humidity and seasonal variability on ambient air quality in a coastal urban area. International Journal of Atmospheric Sciences. https://doi.org/10.1155/2013/264046.

Katsouyanni, K., Touloumi, G., Samoli, E., Gryparis, A., Le Tertre, A., Monopolis, Y., et al. (2001). Confounding and effect modification in the short-term effects of ambient particles on total mortality: Results from 29 European cities within the APHEA2 project. Epidemiology, 12(5), 521-531. 
Laboratório Regional de Engenharia Civil. AREAM. Câmara Municipal do Funchal. (1996). Caso de estudo sobre poluição atmosférica Funchal. Projecto ISIS. http://aream.pt/files/2016 /05/ISIS_Caso_estudo-AR.pdf. Accessed 10 Mar 2018.

Liu, Z., Hu, B., Wang, L., Wu, F., Gao, W., \& Wang, Y. (2015). Seasonal and diurnal variation in particulate matter (PM10 and PM2.5) at an urban site of Beijing: Analyses from a 9year study. Environmental Science and Pollution Research, 22(1), 627-642.

López-Villarrubia, E., Ballester, F., Iñiguez, C., \& Peral, N. (2010). Air pollution and mortality in the Canary Islands: A timeseries analysis. Environmental Health, 9, 8.

Madeira em Números. (2016). Direção Regional de Estatística da Madeira. Funchal: D.R.E.M. https://estatistica.madeira.gov. pt/download-now-3/multitematicas-gb/multitematicas-mn$\mathrm{gb} /$ multitematicas-mn-publicacoes-gb/finish/213-madeiraem-numerospublicacoes/8729-madeira-em-numeros-2016. html. Accessed 18 Apr 2018.

Macedo, M., Lima, M. J., Silva, A. O., Alcantara, P., Ramalhinho, V., \& Carmona, J. (2010). Prevalence, awareness, treatment and control of hypertension: The PAP study. Journal of Hypertension, 23(9), 1661-1666.

Mills, N. L., Donaldson, K., Hadoke, P. W., Boon, N. A., MacNee, W., Cassee, F. R., et al. (2009). Adverse cardiovascular effects of air pollution. Nature Clinical Practice Cardiovascular Medicine, 6, 36-44.

Moreira, C. S., Alcântara, P., \& Nicolau, V. (2017). Insuficiência cardíaca e patologia associada em Portugal entre 2000 e 2005. Revista Portuguesa de Cardiologia, 36, 194.

Nebel, B. J., \& Wright, R. T. (1993). Environmental science: The way the world works (4th ed.). New Jersey: Prentice Hall.

Newby, D. E., Mannucci, P. M., Tell, G. S., Baccarelli, A. A., Brook, R. D., Donaldson, L., et al. (2015). Expert position paper on air pollution and cardiovascular disease. European Heart Journal, 36(2), 83-93b.

Peters, A. (2005). Particulate matter and heart disease: Evidence from epidemiological studies. Toxicology and Applied Pharmacology, 207(2 Suppl), 477-482.

Peters, A., Dockery, D. W., Muller, J. E., \& Mittleman, M. A. (2001). Increased particulate air pollution and the triggering of myocardial infarction. Circulation, 103(23), 2810-2815.

Peters, A., von Klot, S., Mittleman, M. A., Meisinger, C., Hormann, A., Kuch, B., et al. (2013). Triggering of acute myocardial infarction by different means of transportation. European Journal of Preventive Cardiology, 20, 750-758.

Pinheiro, S. A., Saldiva, P. H., Schwartz, J., \& Zanobetti, A. (2014). Efeitos isolados e sinérgicos do MP10 e da temperatura média na mortalidade por doenças cardiovasculares e respiratórias. Revista de Saúde Pública, 48(6), 881-888.

Pope, C. A., Reunlund, D. G., Kfoury, A. G., May, H. T., \& Horne, B. D. (2008). Relation of heart failure hospitalization to exposure to fine particulate air pollution. American Journal of Cardiology, 102(9), 1230-1234.

Querol, X. (2008). Calidad del aire, partículas en suspensión y metals. Revista Española de Salud Pública, 82, 447-454.

Querol, X., Alastuey, A., Pandolfi, M., Reche, C., Pérez, N., \& Minguillón, M. C. (2014). 2001-2012 trends on air quality in Spain. Science of the Total Environment, 490, 957-969.

Rich, D. Q., Kipen, H. M., Zhang, J., Kamat, L., Wilson, A. C., \& Kostis, J. B. (2010). Triggering of transmural infarctions, but not nontransmural infarctions, by ambient fine particles. Environmental Health Perspectives, 118, 1229-1234.

Schwartz, J. (2004). The effects of particulate air pollution on daily deaths: A multi-city case crossover analysis. International Journal of Occupational and Environmental Health, 61(12), 956-961.

Shah, A. S., Ferry, A. V., \& Mills, N. L. (2017). Cardiac biomarkers and the diagnosis of myocardial infarction in women. Current Cardiology Reports, 19(5), 40.

Stähli, B. E., Gebhard, C., Yonekawa, K., Gebhard, C. E., Altwegg, L. A., von Eckardstein, A., et al. (2015). Genderrelated differences in patients presenting with suspected acute coronary syndromes: Clinical presentation, biomarkers and diagnosis. Cardiology, 132(3), 189-198.

Strobel, N. A., Fassett, R. G., Marsh, S. A., \& Coombes, J. S. (2011). Oxidative stress biomarkers as predictors of cardiovascular disease. International Journal of Cardiology, 147(2), 191-201.

Strunz, C. M., Araki, L. M., Nogueira, A., \& Mansur, A. P. (2011). Gender differences in serum CK-MB mass levels in healthy Brazilian subjects. Brazilian Journal of Medical and Biological Research, 44(3), 236-239.

Sunyer, J., Ballester, F., Tertre, A. L., Atkinson, R., Ayres, J. G., \& Forastiere, F. (2003). The association of daily sulfur dioxide air pollution levels with hospital admissions for cardiovascular diseases in Europe (The Aphea-II study). European Heart Journal, 24(8), 752-760.

Tadano, Y. S., Ugaya, C. M., \& Franco, A. T. (2009). Método de regressão de Poisson: metodologia para avaliação do impacto da poluição atmosférica na saúde populacional. Ambiente \& Sociedade, 12(2), 241-255.

Townsend, N., Nichols, M., Scarborough, P., \& Rayner, M. (2015). Cardiovascular disease in Europe - epidemiological update 2015. European Heart Journal, 36(40), 2696-2705.

United States Environmental Protection Agency (2018). National Ambient Air Quality Standards Table. https://www.epa. gov/criteria-air-pollutants/naaqs-table. Accessed 13 August 2018.

Vasconcelos, J. (2012). Bioclima, saúde e qualidade da habitação em Portugal: Papel da exposição ao frio na incidência de doenças coronárias agudas. $\mathrm{PhD}$ Thesis, Faculdade de Ciências e Tecnologia e Universidade Nova de Lisboa.

Wilson, T. E., Gao, Z., Hess, K. L., \& Monahan, K. (2010). Effect of aging on cardiac function during cold stress in humans. American journal of physiology. Regulatory, integrative and comparative physiology, 298(6), 1627-1633.

World Health Organization. (2016). WHO Expert Consultation: Available evidence for the future update of the WHO Global Air Quality Guidelines (AQGs) (pp. 1-50). WHO Regional Office for Europe. http://www.euro.who.int/_data/assets/pdf file/0013/301720/Evidence-future-update-AQ Gs-mtg-reportBonn-sept-oct-15.pdf?ua=1. Accessed 10 Aug 2018.

World Health Organization. (2018). Health risk assessment of air pollution - General principles (pp. 1-40). WHO Regional Office for Europe. http://www.euro.who.int/_data/assets/pdf file/0006/298482/Health-risk-assessment-air-pollution-Generalprinciples-en.pdf?ua=1. Accessed 10 Aug 2018.

Publisher's Note Springer Nature remains neutral with regard to jurisdictional claims in published maps and institutional affiliations. 